\title{
INTEGRATION OF MALAY CULTURAL IDENTITY WITH ISLAMIC RELIGION
}

\author{
Sohirin Mohammad Solihin \\ International Islamic University Malaysia (IIUM) \\ email: sohirin@iium.edu.my
}

\begin{abstract}
Malay culture is the unique racial and ethnic identity of the Malay people that cannot be separated from the teachings of Islam that are embraced by Malay society. This article explains that Malay culture is firmly rooted in Islamic values. The doctrine of the belief in monotheism in Islam is the normative and philosophical basis of Malay culture. Meanwhile the teachings of Islam about truth and justice become the spirit that animates the behavior of the Malay community in their daily lives. Malay culture integrated with Islamic values must be well communicated in the interaction of Malays with non-Malay races and ethnicities. This is important so that the values of Islam as a mercy for the universe can be felt by all humans. The final part of this paper shows how Malay Muslims have not yet understood Malay culture in a broader perspective. Culture is only understood as cultural art, whereas Malay culture also includes aspects of politics, social, science, economics and so on. On the other hand, the behavior of some Malays in these aspects also does not reflect the ideal Malay culture imbued with Islamic values.
\end{abstract}

Keywords: integration, Malay cultural identity, Islamic religion

\section{Introduction}

Generally understandable, when people talk about Malay culture therein they will describe the values of religious beliefs, namely Islamic values. This is one form of integration of Islam and the Malay World which can give birth to Islamic enthusiasm and fanaticism for the Malay community. This then gave birth to the slogans "Malay World, Muslim World" and "No Islam, not Malay", although this fact is still being debated among them (Almudra 2008, 13). From an etymological perspective, culture in Malay is known as a civilization derived from the Arabic word, adab which literally means ethics or behavior. It is true that religion plays an important role in shaping the views and character of national civilization. In other words, culture includes beliefs or religions that shape the cultural appearance of a society.

The relationship between Malay culture and religious identity can be traced to the term civilization which has become an acronym in Malay vocabulary. Naquib alAttas (1984) assume that the word civilization comes from the word al-din (religion). This signifies the concept of culture that cannot be separated from religion. The relationship between culture and religious identity is also justified by contemporary scholars such as Ismail al-Faruqi $(1998,45)$ which considers that culture must be built on the basis of religious beliefs. He further argues that monotheism is the main cause of the emergence of Islamic culture.

Malay culture becomes the identity of the people because it has become part of the life of the Malay community. History has shown that the Malay-Islamic world is an 
important center of civilization, a center for cultural development and a center for trade (Fariza Md. Sham 2002). Islamic values are the basis and characteristics of Malay people in their behavior. "Malay-Islam", "Malay World, Islamic World" and "No Islam, not Malay" are important phenomena discussed, because it shows the integration between Malay culture and Islam and even Islam then becomes the basis of Malay behavior.

The slogan "No Islam is not Malay", illustrates that the values of Islamic teachings can be a fortress for people's lives in the face of globalization. All of this depends on Muslims whether they want to hold fast to the true teachings of Islam that originate from the Koran and al-Hadith. A solid and intact grip on these two sources is able to save humanity, especially Muslims so that they do not fall into munkar.

Research on Malay culture was carried out by Baharuddin bin H. Puteh and Mohamad Nazli bin H. Omar (2014). They write about "Islam and Malay Culture in the Era of Globalization". The results of both studies indicate that globalization can exert influence on the lives of Malay-Muslims and tends to have a negative influence. Different from this research, the focus of this article is on the integration of Malay identity with Islam which is the basis of Malay society reflecting daily culture, attitudes and behavior. When people mention Malay, Islamic values will be portrayed in it. Islam became the basis for the Malay community in developing their culture and identity.

\section{Islamic Culture and Malay Culture}

In Arabic, culture is usually associated with the word al-tsaqafah which gives different meanings such as intelligence or competence and accuracy of understanding (sur'ah al-fahm). Sometimes the word al-tsaqafah also gives the meaning of understanding (al-idrak) and to get something as mentioned in the following verses.

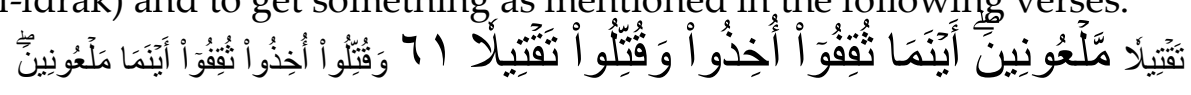

Meaning: In a state of cursing. Wherever they are found, they are captured and killed with the greatest possible. (Al-Ahzab: 61)

In another verse Allah SWT also says

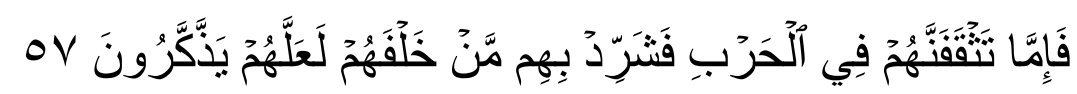

Meaning: If you meet them in battle, then divorce the people behind them by (crushing) them, so they take lessons (Q.S. Al-Anfal: 57).

If culture is associated with Islam, then the definition of Islamic culture in the hands of Muslim scholars refers to the following categorization: first, the development of Muslims. These are defined as the principles of activities based on Islam (past, present and future) in religion, language, history and civilization, shared values and goals.

Second, orientation which makes Islamic sciences (al-Ilmu al-Islamiyyah) as the main source. In this aspect, the definition of Islamic culture reflects the synonym of Islamic studies. The definition says, knowledge of religious principles is related to its activities in the past, present or future that originate from these principles. Such 
definitions represent all aspects of Islamic studies that emerge from the Qur'an and Sunnah including what has been added by Muslim scholars such as the interpretation of the Qur'an, Hadith, Islamic jurisprudence, and the history of the Prophet (PBUH).

Third, the orientation of thought which considers that Islamic culture is a new phenomenon that addresses a variety of different topics. This knowledge results from the emergence of new events and ideas and contemporary studies. Therefore, the definition says, 'Knowledge is related to contemporary challenges and the struggle of Muslims and Islam at the same time'. The same definition says, "Science deals with comprehensive methods of values, systems, thinking and the legacy of human criticism".

The word Malay can be related to race and religion. In the Indonesian context, Malay is not as specifically associated with religion as Malaysia is. If there are ethnic Malays in Indonesia who adhere to a religion other than Islam, then in Malaysia, the word Malay is identical to religion (Islam). When someone converts to Islam, they are automatically known as Malay even though their race is Indian or Chinese. The Malay world can bring certain differences and orientations to life whenever it is applied to race and religion. Burma, Vietnam and even the Philippines can be considered as Malays who follow other religions.

Returning to the understanding of Malay culture, the word civilization is associated with adab (ethics or procedures) which is the main source of Malay cultural appearance. It seems that the word civilization is somehow related to the hadith of the Prophet (PBUH) which says:

Meaning: My Lord taught me ethics to make it a better moral behavior.

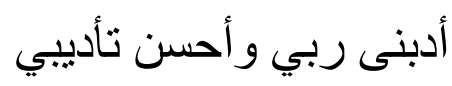

Culture is usually understood as customary practices and traditions in the community. While al-hadarah (civilization) is always given an understanding related to the theory of knowledge and science, the progress and progress of the nation in sociopolitical and infrastructure and others. The scope of culture encompasses all human activities, such as communication, behavior, beliefs, and sincerity.

Malay culture, which mostly originated from Islam, has faced other cultural influences. Malay culture is currently faced with challenges from outside influences. However, we must see that whatever the challenges or competition from the influence of other cultures, Islamic culture remains intact. The question is how to maintain a culture based on religious identity? As has been defined that the soul of culture comes from religion (Malay). Therefore it is very important that Muslim behavior reflects the character of religion in all aspects of life. It is ironic that most Muslim cultures instead discuss only certain aspects of cultural behavior that originate from religious beliefs. Islamic culture does not represent the essence of belief but is only superficially understood as limited to cultural traditions in society.

Another term that connotes Malay culture is the word culture or culture which contains the meaning of mind (a virtue) and power (practice). This gives another indication that Malay culture cannot be separated from good deeds in society. Islam is a major factor in the formation of culture in the Malay world. This can be seen from the beginning of the arrival of this religion into the Malay region. The influence of Islam on Malay culture is clearly seen in various aspects. The original Malay text is written in Arabic script. Some historical data notes that access to Malay with Arabic script opened 
the way to understanding or at least the ability to read the Qur'an. Before the emergence of the colonial administration's policy of introducing Roman scripts which they considered a source of modernity to replace Arabic characters in Malay writing, Arabic script had been used in Malay culture. This shows a strong relationship between religious identity and local culture.

\section{Monotheism as the Basis of Malay Culture}

As long as the explanation about Islamic culture is identical to the Malay character, it can be claimed that the value of Tawheed is a reference for all human activities in attitude. Monotheistic value is the concept of monotheistic faith which is the motivation and belief of Muslim people. The basic concept of monotheism is not only limited in the attributes of God, but is also focused on the concepts of truth and justice that characterize divine behavior. The character of God's justice must be actualized in human life while interacting with other humans. God's behavior towards His servant needs to be demonstrated in Muslim cultural behavior in life.

Because Malay culture originates from religion, it must be rooted in the flow of thought which originates from the concept of monotheism. In this case it is understood that God symbolizes truth and the source of justice. This can be referred to a lot of evidence in various places in the Qur'an that says,

Meaning: Truth comes from your Lord; so I have no doubts.

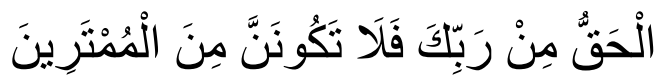

When the doctrine delivered to the Prophet Muhammad is considered extraordinary, it means the cultural behavior of adherents of Islam must reflect compliance with the doctrine of justice. The results of following the truth must be manifested in cultural integrity. Apart from the theological concepts that signify monotheistic beliefs, Muslims must be culturally obsessed with promoting justice in dealing with others. In a sociological context, spiritual practice must also be sought in order to train individuals to be honest, timely, and fair.

Those who claim to accept Islam as a religion are expected to produce quality cultures that can be taken as role models by others. The concept of witness testimony known as al-shahadah also means "only accepting the truth or justice and negating falsehood, injustice and all negative characters".

The expression of Laa Ilaaha Illallah (there is no god but Allah) is expected to produce cultural integrity that is only to focus on the truth related to socio-economic and political activities. Cultural behavior based on truth will be a source of strength and cultural perfection and even life balance, (while) saying: "I am your highest god" (Q.S. Al Nazi' at [79]: 24).

This indicates that the behavior of the Malay-Islamic community stems from the stability of the aqeedah and implements the teachings of Islam as well as possible. This then became the identity of the Malay-Islamic community and culture.

\section{Justice as Malay Cultural Behavior}


Because Malay cultural traditions cannot be separated from religion, the Malay language heritage is also heavily influenced by Islamic teachings. This, among others, can be understood from certain terms such as fair, safe and secure, and deliberation. Such words are derived from Arabic, but are closely related to religion. The word justice comes from al-adl wa al-is. This means that Malay culture is religiously concerned with upholding justice in society both at the personal and community level. Likewise, the word deliberation also ensures that for the Malay community everything must be done on the basis of consultation to reach mutual agreement.

In other words, Malay culture must reflect a loyal character to uphold truth and justice in a society that is spread through cultural interaction. Only then can Islamic culture be directed at a global level to promote compassion for all humanity as reflected in this verse,

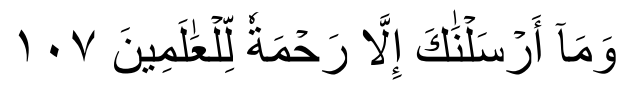

Meaning: And we have not sent you, but to (be) a mercy to the worlds (Q.S. Al Anbiya' [21]: 107).

Cultural behavior is in fact an effective instrument for spreading truth and justice in society. This is a way to attract sympathy from the universal message conveyed by the Prophet. Unfortunately many Muslims consider culture to be limited to something like entertainment such as cinema, film, music performances and also art. They must expand this narrow understanding because cultural behavior actually covers all aspects of human activity in this world.

Related to the just behavior of the Prophet sallallaahu 'alaihi wa sallam, in a hadith Qudsi, states that Allah says:

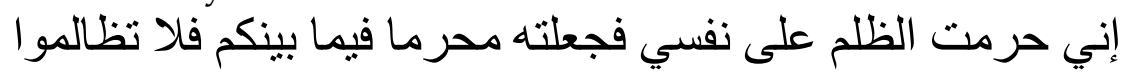

It means: Verily, I have forbidden the tyranny of myself and I have forbidden it (wrongdoing) among you, so do not you behave to each other wrongfully. (Muslim n.d.)

There is plenty of evidence in the Qur'an regarding the application of justice which represents essential doctrine. This is the evidence,

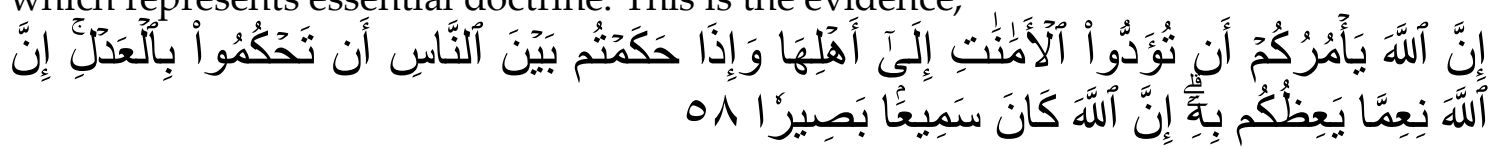

Meaning: Verily, Allah tells you to deliver the message to those who are entitled to receive it, and (tells you) if you establish a law between humans so that you determine it fairly. Surely Allah gives you the best teaching. Allah is All-Hearing, All-Seeing. (Q.S. An-Nisa: 58)

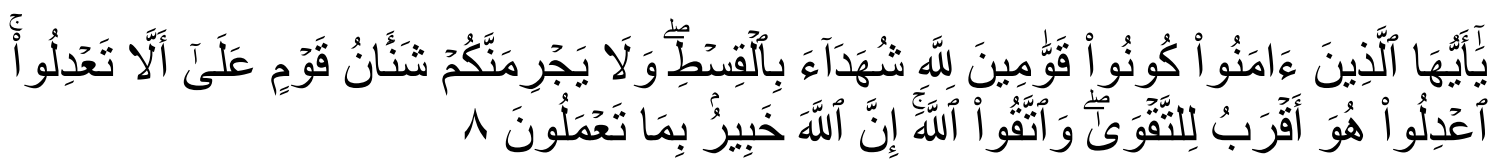

Meaning: Verily, God tells you to deliver the message to those who are titled to receive it, and (tells you) if you establish a law between humans so that you determine it fairly. Surely Allah gives you the best teaching. God is All-Hearing, All-Seeing. (Q.S. Al-Maidah: 8)

Thus, a believer will stand firm for God, as a witness for fair transactions, and not make hatred towards others make him deviate from justice. Be a just person because justice is close to piety, and fear God, because surely Allah knows what you are doing. 


\section{Cultural Communication}

God laid down universal principles to maintain peaceful co-existence between humans in the community. Humans cannot isolate themselves, instead they must communicate with others and interact by using certain behaviors (Zaid 1988). This system is solely aimed at avoiding conflict and actualizing peaceful missions in this world and to guide humanity to behave as the Caliph of Allah who bears witness to truth and justice in society.

There is no doubt that God declared Himself to be fair. Muslims and Malays in particular must show culture in the image of God throughout their activities without the intention of sacrificing others. At the same time they are also culturally reminded to form alliances with those who love God to create networks of goodness, justice and prosperity. Instead, they should not collaborate with those who adopt cultural practices that conflict with truth and justice that can cause crises (Al Sha'rawi 1997, 878).

Muslims must obey the norms of communication; with the use of courtesy, do not use harsh words and rudeness that can damage the relationship between them. The principle of such communication from an Islamic perspective is solely aimed at maintaining peace and tranquility. Even at the family level, the relationship between husband and wife can only be maintained if they respect each other, have mutual understanding and perpetuate a sense of solidarity to help each other, avoiding rude behavior in their daily communication.

\section{Malay Cultural Dilemma}

In the first part we have explained that the concept of culture in the Malay world in particular and in most of the Muslim world in general is understood in a narrow sense which is limited to certain traditions such as festivals, religious ceremonies and also art. They hardly connect cultural behavior that covers all aspects of activities. Meanwhile the culture, Muslims and the Malay race do not reflect cultural behavior that must be applied in the community.

In the field of science and science, for example the culture of iqra (reading) is not as expected. Although Islamic doctrine focuses primarily on education, cultural learning in the Muslim world in general and the Malay world in particular still does not meet the conditions needed to compete with other nations. Most Muslim countries, including the Malay world, still rely on others in managing their resources. Supposedly, when we consider religion as a way of life, at the same time we must prepare resources and culture to achieve excellence that enables people to be able to compete with others in terms of goodness, prosperity and justice. When God declares religious supremacy, it means that culturally Muslims must excel in all fields.

Let's contemplate what the Islamic dictum says as stated in the following evidence that says,

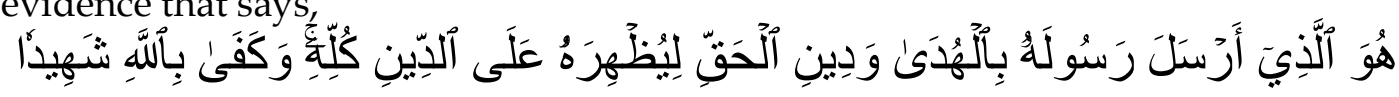

Meaning: He is the one who sent His Messenger by bringing instructions and religion that He has the right to win over all religions. And Allah is sufficient as a witness (Q.S. Al Fath [48]: 28). 
The supremacy of Islam which is characterized by the concepts of truth and justice is to guarantee peace and security in all aspects of human activity. This means Muslim cultural behavior must reflect supremacy and compete in cultural behavior with integrity. It should be emphasized here that cultural education and learning in the Malay world in particular and the Muslim world in general need to be focused on achieving cultural excellence in order to be able to compete in the midst of globalization.

Another aspect that can be seen seriously is related to cultural integrity. As we know that religious identity is characterized by truth and justice. Islam which is the source of culture must be understood in the sense of maintaining peace through the application of integrity. The cultural behavior of some Malays does not represent integrity. Unfair competition between various groups, fraud, and insincerity is still very rampant in society.

Another aspect that needs attention is the socio-political culture. Many politicians do not reflect integrity by paying attention to truth and justice. Political competition and the process of democratization remain unclear and not as expected. However, this kind of phenomenon does not only occur in Malay culture but rather represents a general phenomenon of the Muslim world in general. In the Arab world which represents the 'mainstream of Islam', the system of government, the transformation of power, socio-political, economic, and cultural activities are still far from systems and values of integrity. In certain cases in the Malay country with the largest Muslim population in the world (Indonesia), for example, the behavior of political culture represented in political parties across ideological orientations is often at odds with the divine value system. This can be seen from the high involvement of high government officials in corruption cases.

In Malaysia, communication between political groups sometimes does not reflect the value of religious identity. Mutual accusations related to moral issues and corruption between the ruling party and the opposition still emerge from time to time. The case of these two Malay countries is contrary to the religious cultural identity that became the identity of Malays.

\section{Conclusion}

Malay culture and Islamic values are like two sides of a coin that cannot be separated from one another. The two are integrated in such a way that although they can be distinguished, they are difficult to separate. Islam, both as a doctrine and as a behavior, has become the cultural identity of the Malays. Islamic values have made Malay culture a "high culture" manifested in all aspects of Malay people's lives (social, economic, political, government, education, traditions, customs, and ways of life). Therefore the slogans "Malay World Islamic World" and "No Islam not Malay" become very relevant to the world and Malay civilization in Southeast Asia (especially Malaysia, Brunei Darussalam, and Indonesia). Malay identity and Malayness should be reflected in daily attitudes and behavior, both in personal life and in interactions with others. 


\section{Bibliography}

Al-Qur'an Al-Karim

Al-Attas, Syed Muhammad Naquib. 1984. Konsep Pendidikan Dalam Islam: Suatu Rangka Pikir Pembinaan Filsafat Pendidikan Islam. Bandung: Mizan.

al-Faruqi, Ismail Raji'. 1998. Cultural Atlas of Islam. New York: Macmillan.

Almudra, Mahyudin. 2008. Redefinisi Melayu, Upaya Menjembatani Perbedaan Konsep Kemelayuan Bangsa Serumpun. Yoyakarta: Balai Pengkajian dan Pengembangan Budaya Melayu.

Fariza Md. Sham. 2002. Peranan Islam Dalam Sejarah Dan Kebudayaan Melayu." Dalam Dakwah Kepada Masyarakat Muslim Di Malaysia. Bangi.

Muslim, Imam. tt. Shahih Muslim.

Puteh, H, Mohamad Nazli, and H Omar. 2014. "Islam Dan Kebudayaan Melayu Di Era Globalisasi Di Malaysia." Sosial Budaya 11(1): 115-23. https://www.neliti.com/publications/40475/islam-dan-kebudayaan-melayu-di-eraglobalisasi-di-malaysia (December 29, 2018).

Al Sha'rawi, Muhammad Mutawali. 1997. Tafsir Al-Sha'rawi. Cairo: MaÏÉbiÑ Akhbar al-Yawm. 